\title{
New species of the dinoflagellate cyst genus Svalbardella Manum, 1960, emend. from the Paleogene and Neogene of the northern high to middle latitudes
}

\author{
Kasia K. Śliwińska ${ }^{1}$ and Martin J. Head ${ }^{2}$ \\ ${ }^{1}$ Department of Stratigraphy, Geological Survey of Denmark and Greenland, \\ GEUS, Øster Voldgade 10, 1350 Copenhagen K, Denmark \\ ${ }^{2}$ Department of Earth Sciences, Brock University, 1812 Sir Isaac Brock Way, \\ St. Catharines, Ontario L2S 3A1, Canada \\ Correspondence: Kasia K. Śliwińska (kksl@geus.dk)
}

Received: 17 March 2020 - Revised: 27 June 2020 - Accepted: 7 July 2020 - Published: 10 September 2020

\begin{abstract}
Species of the fusiform peridiniacean dinoflagellate cyst genera Svalbardella Manum, 1960, emend. (Eocene-Oligocene) and Palaeocystodinium Alberti, 1961 (Late Cretaceous-Miocene), have been examined from the high to middle latitudes of the Northern Hemisphere: Spitsbergen, Norwegian-Greenland Sea, Labrador Sea, western North Atlantic, and the North Sea basin. The genus Svalbardella is emended to comprise species with smooth or finely ornamented surfaces and for which one or both horns are bluntly rounded. Svalbardella clausii sp. nov. has a narrow range restricted to the lowermost Chattian (close to the NP24-NP25 boundary and within Chron C9n), and it therefore appears a useful stratigraphical marker. This species has a wide distribution across the North Atlantic, having been reported from the North Sea basin, western North Atlantic, and the Labrador Sea. Svalbardella clausii sp. nov. overlaps stratigraphically with the reoccurrence interval of Svalbardella cooksoniae Manum, 1960, and spans the Oi-2b cooling maximum. Its presence may therefore be related to the establishment of cooler surface waters at this time. Svalbardella kareniae sp. nov. has a discordant occurrence: Lower Oligocene and Lower Miocene of the Norwegian Sea at Deep Sea Drilling Project Site 338 and Ocean Drilling Program Site 643, respectively, and mid-Oligocene of the North Sea. Its distribution suggests that Svalbardella kareniae sp. nov. favours more open marine conditions. Palaeocystodinium obesum Fensome et al., 2009, described from offshore eastern Canada where it has a highest occurrence in the Lower Oligocene, is emended to include specimens with a finely ornamented periphragm and traces of tabulation in addition to the archeopyle.
\end{abstract}

\section{Introduction}

The fossil dinoflagellate cyst genus Svalbardella Manum, 1960, is known from the Middle Eocene to Oligocene primarily of the Northern Hemisphere: Spitsbergen (Manum, 1960), Western Siberia (Iakovleva, 2011), Greenland (Birkenmajer et al., 2010; Nøhr-Hansen, 2003), the Norwegian-Greenland Sea (Eldrett et al., 2004, 2019; Śliwińska and Heilmann-Clausen, 2011), Arctic Canada (Ioannides, 1986), the North Sea basin (Heilmann-Clausen and Van Simaeys, 2005; Schiøler, 2005; Śliwińska, 2019; Van Simaeys et al., 2005), the western North Atlantic (Egger et al., 2016; Firth et al., 2013; Head and Norris, 1989), and the Paratethys (e.g. Pross et al., 2010). There are, however, a few records of Svalbardella species from the southern high latitudes (e.g. Brinkhuis et al., 2003; Van Simaeys et al., 2005).

Currently only two species are formally assigned to this genus, Svalbardella cooksoniae Manum, 1960, and Svalbardella partimtabulata Heilmann-Clausen and Van Simaeys, 2005. Svalbardella cooksoniae ranges from Chron C19r ( 42.2 Ma; Eldrett et al., 2004) to Chron C9n (Coccioni et al., 2018; Pross et al., 2010), whereas Svalbardella partimtabulata is presently known only from a narrow in- 
terval within the Middle Eocene (Chron C18r-C18n; midBartonian; Heilmann-Clausen and Van Simaeys, 2005; Śliwińska et al., 2016; Thomsen et al., 2012) of Denmark. Notably, in the Oligocene succession of the North Sea basin, the Norwegian-Greenland Sea, and the Paratethys, Svalbardella cooksoniae occurs in several discrete intervals. Three of these intervals are synchronous with Oligocene cooling maxima (Śliwińska, 2019; Śliwińska and Heilmann-Clausen, 2011; Van Simaeys et al., 2005). Morphologically, the genus Svalbardella is most similar to Palaeocystodinium Alberti, 1961. Common features are as follows: (i) standard peridiniacean tabulation (Fensome et al., 1993) and fusiform shape, (ii) single apical and antapical horns, (iii) cornucavate wall, (iv) an ellipsoidal endocyst, and (v) a 2a intercalary archeopyle. It is generally accepted that Svalbardella differs from Palaeocystodinium in having bluntly rounded apical and antapical horns and indications of tabulation other than the archeopyle. However, the distinction between the two genera based on these two features is not straightforward. Although expression of tabulation is not in the original diagnosis of Svalbardella, the description of the genus does state that "there are indications of plates and a longitudinal furrow [sulcus] in the type species" (Manum, 1960, p. 21). However, under the description of the type species, Svalbardella cooksoniae, "Some specimens are recognizable by their shape only, the fine ornamentation and other details not having preserved" (Manum, 1960, p. 22). Moreover, even though in the original generic description of Palaeocystodinium the tabulation is expressed by archeopyle alone, several species assigned to this genus show signs of additional tabulation. The cingulum and sulcus are typically observed in Palaeocystodinium hampdenense (Wilson, 1977) Wrenn and Hart, 1988, and sporadically in Palaeocystodinium australinum (Cookson, 1965) Lentin and Williams, 1976. Both species were originally assigned to Svalbardella. Regarding Palaeocystodinium minor Strauss in Strauss et al., 2001, specimens "may display very faint longitudinal parasutural ledges at the horn bases" (Strauss et al., 2001, p. 407).

Already in 1967, Evitt (1967, p. 37) considered Palaeocystodinium to be a junior synonym of Svalbardella. Further, Lindgren (1984) argued that discriminating two taxa at the rank of genus simply because of slight variability in tabulation and horn shape is not reasonable (p. 186), and the author thus suggested that Svalbardella is the senior synonym of Palaeocystodinium. Wrenn and Hart (1988) opposed that notion and argued that the presence of tabulation and broad, rounded horns which are so characteristic of Svalbardella are not highly variable features. Furthermore, the authors observed that "horns in various species of Palaeocystodinium may be pointed or bluntly round, but they are still thin and taper markedly from the area of the central body to their terminations" (Wrenn and Hart, 1988, p. 361). However, in Svalbardella partimtabulata Heilmann-Clausen and Van Simaeys (2005) and Svalbardella kareniae sp. nov. (this study) the antapical horn is long and tapers gradually.
The most recent emendation of Palaeocystodinium restricts this genus to forms with pointed horns (Fensome et al., 2009). However, the literature reveals several distinctive morphotypes with at least one bluntly rounded horn that are assigned either to Svalbardella or Palaeocystodinium (e.g. Damassa et al., 1990; Egger et al., 2016; Poulsen et al., 1996; Schiøler, 2005; Śliwińska et al., 2012) but have never been formally described as species.

In this study, we accept that the presence of at least one bluntly rounded horn is sufficiently distinctive to separate Svalbardella from Palaeocystodinium. Accordingly, Svalbardella is amended to include species with a single bluntly rounded horn. The present study describes two new species, Svalbardella clausii sp. nov. and Svalbardella kareniae sp. nov., from the Oligocene of the North Atlantic region, and discusses their stratigraphical and palaeoenvironmental significance. Additionally, Palaeocystodinium obesum Fensome et al., 2009, is emended.

\section{Material and methods}

This research is based on samples from Spitsbergen, the Norwegian-Greenland Sea, the North Sea basin, the Labrador Sea, and western North Atlantic. The locations of those North Atlantic-Arctic sites where the genus Svalbardella has been reported, including the present study, are shown in Fig. 1 and listed in Table 1. Palynological slides from Sarsbukta, Spitsbergen, studied previously by Manum (1960) were reanalysed by Kasia K. Śliwińska in 2011 during a research stay at the Natural History Museum in Oslo, Norway. The preparation methods are described in Manum (1960). During this visit, palynological slides from Renardodden, Spitsbergen, studied previously by Head (1984), were also examined (and subsequently reexamined by Martin J. Head). Palynological slides from Ocean Drilling Program (ODP) Site 634 in the Norwegian Sea were loaned from the Natural History Museum in Oslo, their preparation having been described in Manum et al. (1989). Palynological slides from the offshore 11/10-1 well, central North Sea, were borrowed from the Norwegian Petroleum Directorate (NPD); the preparation methods for these are described in Śliwińska (2019). Palynological slides from the offshore Nini-1 well in the eastern North Sea were also examined, as were palynological slides from the Harre1 borehole, onshore Denmark. The preparation methods for these slides were described by Śliwińska et al. (2010, 2012). The palynology of Deep Sea Drilling Project (DSDP) sites from the northern North Atlantic and Labrador Sea was previously studied by Damassa et al. (1990). The present research also uses palynological slides from Integrated Ocean Drilling Program (IODP) Leg 342 sites U1411 and U1406 in the western North Atlantic, which were prepared at the Geological Survey of Denmark and Greenland (GEUS) and included in the study by Egger et al. (2016). Several new 
palynological slides from IODP Hole 1411B were prepared for the present study, following the processing methods described in Egger et al. (2016).

Key taxa discussed in the text are presented in Table 1 and on Plates 1-5. The position of each of the photographed specimens is indicated by microscope coordinates $(\mathrm{MC}$; the A point $=0: 4 \times 90: 3[\mathrm{XM} 1 \times \mathrm{YM} 1]$ following the method described in Śliwińska, 2019) and/or an England Finder (EF) reference. The horn length is measured from the tip of the endocyst to the corresponding tip of the pericyst. The type material and the illustrated dinocysts marked with MGUH numbers are stored in the type collection of the Natural History Museum of Denmark (Øster Voldgade 5-7, DK-1350 Copenhagen K, Denmark). The type material and the illustrated dinocyst marked with a PMO number are stored in the type collection of the Natural History Museum in Oslo (Sars' gate 1, NO-0562 Oslo, Norway).

\section{Formal description of new species}

Division Dinoflagellata (Bütschli, 1885) Fensome et al., 1993

Subdivision Dinokaryota Fensome et al., 1993

Class Dinophyceae Pascher, 1914

Subclass Peridiniphycideae Fensome et al., 1993

Order Peridiniales Haeckel, 1894

Family Peridiniaceae Ehrenberg, 1831

Subfamily Deflandreoideae Bujak and Davies, 1983

Genus Svalbardella Manum, 1960, emend.

Type

Manum, 1960, pl. 1, figs. 1-3; text-fig. 2, as Svalbardella cooksoniae.

\section{Original diagnosis}

Shells of planktonic microorganisms. Shape fusiform with somewhat swollen middle part and blunt ends. No appendages. Girdle approximately equatorial. Middle part of shell entirely filled by a thin-walled ellipsoidal body (Manum, 1960, p. 21).

\section{Emended diagnosis}

Cornucavate cysts with a fusiform shape, a single apical and antapical horn, and an ellipsoidal endocyst. One or both horns are conspicuously bluntly rounded. Surface smooth or bears low ornamentation. Cingulum when present is approximately equatorial. Archeopyle 2a intercalary. Other traces of tabulation may be present.
Accepted species

Svalbardella clausii sp. nov., Svalbardella cooksoniae Manum, 1960, Svalbardella kareniae sp. nov., Svalbardella partimtabulata Heilmann-Clausen and Van Simaeys, 2005.

\section{Remarks}

The genus is emended to contain species in which one (e.g. Svalbardella kareniae sp. nov.) or both (e.g. Svalbardella cooksoniae) horns are bluntly and conspicuously rounded.

\section{Stratigraphic range}

The oldest stratigraphic appearance of the genus Svalbardella is reported from Chron C19r; late Lutetian (as Svalbardella cooksoniae) by Eldrett et al. (2004). The youngest stratigraphic appearance is reported from the Early Miocene A. granosa zone of Manum et al. (1989) in ODP Hole 643A (as Palaeocystodinium sp. 2, now Svalbardella kareniae sp. nov.).

Svalbardella clausii sp. nov.

Plate 1A-I

1990 Palaeocystodinium sp. 2; Damassa et al., fig. 5M.

2005 Palaeocystodinium sp. 2 of Damassa et al. (1990); Schiøler, pl. 10, figs. 6-7.

2010 Svalbardella cooksoniae auct. non Manum, 1960; Pross et al., pl. IV, fig. 5.

2010 Svalbardella sp. 1; Śliwińska et al., pl. 1, fig. 4.

\section{Derivation of name}

After Claus Heilmann-Clausen, the PhD supervisor of Kasia K. Śliwińska, for his important contributions to the study of Cretaceous and Paleogene dinoflagellate cysts.

\section{Diagnosis}

A species of Svalbardella with rounded, short apical and antapical horns of approximately equal length. The endocyst is broad with a length approximately 1.5 times the width. The endocyst is ellipsoidal and has a smooth wall. The periphragm is nearly smooth to microrugulate or incompletely microreticulate. On more coarsely ornamented specimens, tabulation may be expressed by the cingulum and/or plates 1a, 3a, 3-5", and/or 1-2'"'!' in addition to the archeopyle. The archeopyle is intercalary type I (2a); adcingular margin of the periarcheopyle slightly overlaps that of the endoarcheopyle (operculum free). 
Table 1. Drill sites and outcrops yielding specimens here attributed to the genus Svalbardella from the North Atlantic-Arctic region illustrated in Fig. 1.

\begin{tabular}{|c|c|c|}
\hline Drill site/outcrop & Taxon & Reference \\
\hline Sarsbukta & Svalbardella cooksoniae holotype & Manum (1960) \\
\hline Renardodden & Svalbardella sp. cf. S. partimtabulata & Head (1984), this study \\
\hline DSDP 908 & Svalbardella sp. 1, Svalbardella spp. & Eldrett et al. (2019), Poulsen et al. (1996) \\
\hline ODP 913 & $\begin{array}{l}\text { Svalbardella cooksoniae, Svalbardella } \mathrm{cf} . \\
\text { S. cooksoniae }\end{array}$ & Eldrett et al. (2004), Firth (1996) \\
\hline DSDP 338 & $\begin{array}{l}\text { Svalbardella kareniae sp. nov. (as Svalbardella } \\
\text { (Palaeocystodinium) spp.) }\end{array}$ & $\begin{array}{l}\text { Eldrett et al. (2004), Manum (1976), } \\
\text { Śliwińska and Heilmann-Clausen (2011) }\end{array}$ \\
\hline ODP 643A & $\begin{array}{l}\text { Svalbardella sp. cf. S. cooksoniae, Svalbardella } \\
\text { sp. } 1, \text { Svalbardella } \mathrm{sp.} 2\end{array}$ & Eldrett et al. (2004), Head and Norris (1989) \\
\hline ODP 985 & Svalbardella cooksoniae & $\begin{array}{l}\text { Eldrett et al. (2019), Williams and Manum } \\
\text { (1999) }\end{array}$ \\
\hline Hellefisk-1 & Svalbardella sp. cf. S. cooksoniae & Nøhr-Hansen et al. (2003) \\
\hline Kap Brewster & Svalbardella sp. & Birkenmayer et al. (2010) \\
\hline $\begin{array}{l}6609 / 11-1,6610 / 2-1 S, 6407 / 9-2 \text {, } \\
\text { and } 6407 / 9-5\end{array}$ & Svalbardella cooksoniae & Eidvin et al. (2007) \\
\hline $11 / 10-1$ & Svalbardella cooksoniae & $\begin{array}{l}\text { Śliwińska (2019), Śliwińska and Heilmann- } \\
\text { Clausen (2011) }\end{array}$ \\
\hline Alma-1X & $\begin{array}{l}\text { Svalbardella cooksoniae, Svalbardella cf. cook- } \\
\text { soniae, Svalbardella clausii sp. nov. (as Palaeo- } \\
\text { cystodinium sp. } 2 \text { of Damassa et al., 1990) }\end{array}$ & $\begin{array}{l}\text { Schiøler (2005), Śliwińska and Heilmann- } \\
\text { Clausen (2011) }\end{array}$ \\
\hline Nini-1 & $\begin{array}{l}\text { Svalbardella clausii sp. nov. holotype (as Sval- } \\
\text { bardella sp. 1), Svalbardella sp., Svalbardella } \\
\text { cooksoniae }\end{array}$ & $\begin{array}{l}\text { Clausen et al. (2012), Śliwińska (2019), } \\
\text { Śliwińska et al. (2010, 2014a) }\end{array}$ \\
\hline Mona-1 & Svalbardella sp. & $\begin{array}{l}\text { Śliwińska and Heilmann-Clausen (2011), } \\
\text { Van Simaeys et al. (2005) }\end{array}$ \\
\hline Harre-1 & $\begin{array}{l}\text { Svalbardella kareniae sp. nov. (as Palaeocysto- } \\
\text { dinium sp. 1), Svalbardella cooksoniae, Sval- } \\
\text { bardella sp. } 1\end{array}$ & Śliwińska et al. (2012), this study \\
\hline Kysing-4 & Svalbardella partimtabulata holotype & Heilmann-Clausen and Van Simaeys (2005) \\
\hline $\begin{array}{l}\text { Kallo, Hingene-Wintham boring } \\
42 \mathrm{E}-212\end{array}$ & Svalbardella sp. indet. & De Coninck (1996) \\
\hline Leluchów & Svalbardella sp. & Gedl (2004) \\
\hline $\begin{array}{l}\text { Umbria-Marche (incl. the Massi- } \\
\text { core borehole, as well as Contessa, } \\
\text { Pieve d'Accinelli, and Monte } \\
\text { Cagnero outcrop sections) }\end{array}$ & Svalbardella cooksoniae, Svalbardella sp. & $\begin{array}{l}\text { Van Mourik and Brinkhuis (2005), } \\
\text { Van Simaeys et al. (2005) }\end{array}$ \\
\hline ODP 647A & $\begin{array}{l}\text { Svalbardella cooksoniae, Svalbardella } \text { sp. cf. } \\
\text { S. cooksoniae, Svalbardella } \text { sp. } 1 \text {, } \\
\text { Svalbardella } \mathrm{sp} .2\end{array}$ & Firth et al. (2013), Head and Norris (1989) \\
\hline DSDP 112 & $\begin{array}{l}\text { Svalbardella clausii sp. nov. (as Palaeocysto- } \\
\text { dinium sp. 2) }\end{array}$ & Damassa et al. (1990), this study \\
\hline Cumberland B-55 & Svalbardella sp. Wilson, 1971 & Barss et al. (1979) \\
\hline IODP U1405, U1406, U1411 & Svalbardella $\mathrm{sp}$ & Egger et al. (2016) \\
\hline
\end{tabular}




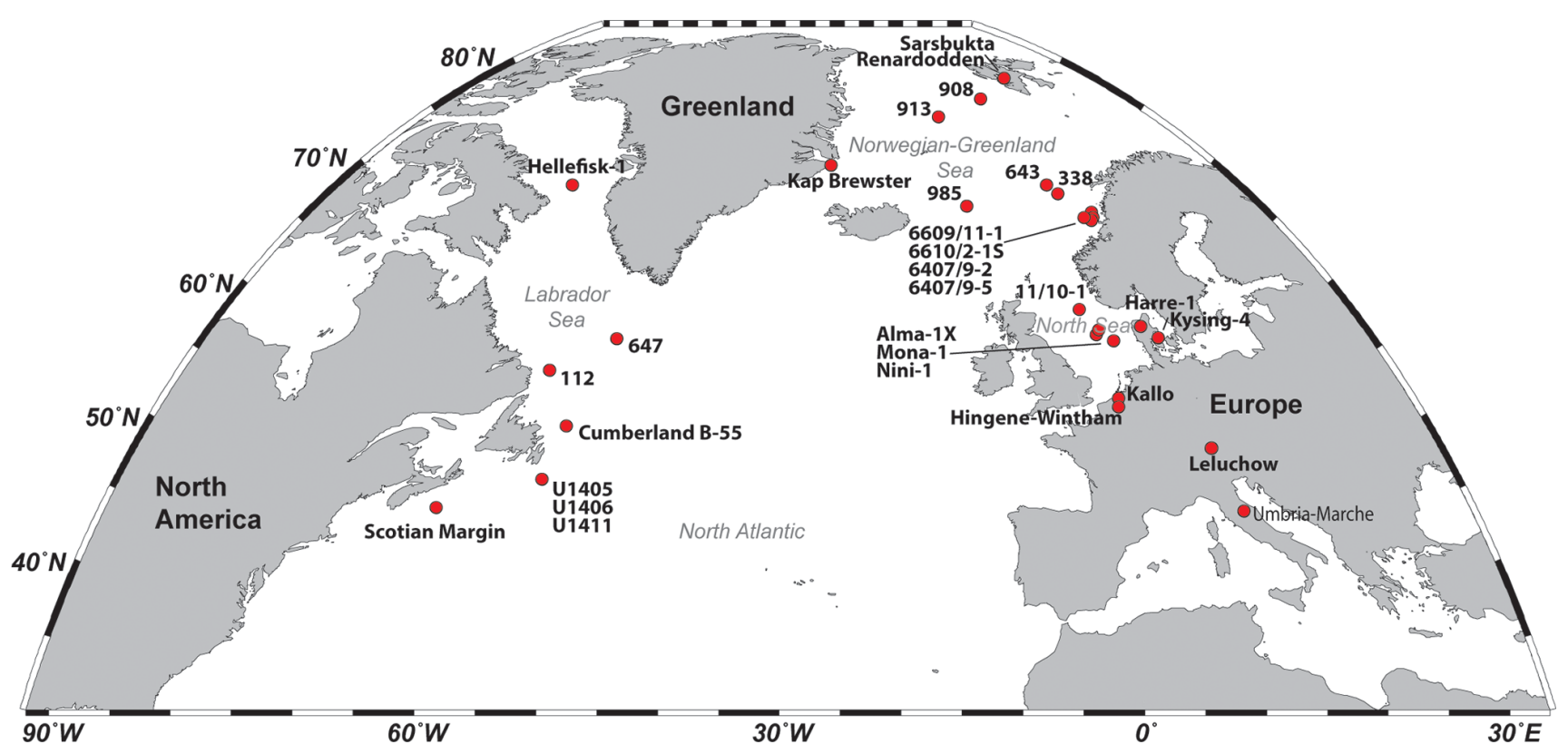

Figure 1. The distribution of drill sites and outcrops where Svalbardella specimens have been reported (see Table 1). Modified from Egger et al. (2016). Reprinted from Review of Palaeobotany and Palynology, 234, Egger, L. M., Śliwińska, K. K., van Peer, T. E., Liebrand, D., Lippert, P. C., Friedrich, O., Wilson, P. A., Norris, R. D., and Pross, J.; Magnetostratigraphically-calibrated dinoflagellate cyst bioevents for the uppermost Eocene to lowermost Miocene of the western North Atlantic (IODP Expedition 342, Paleogene Newfoundland sediment drifts), 159-185, Copyright (2016), with permission from Elsevier.

\section{Holotype}

Slide 158L-2; MGUH no. 33445, EF reference S23/1, MC $23 \times 98.2$. Ditch cutting sample from the eastern North Sea basin, Nini-1 well; depth: $1100.0 \mathrm{~m}$ below kelly bushing (mbKB). Dated to earliest Chattian. Slide is curated at the Geological Museum of the University of Copenhagen. Plate $1 \mathrm{~A}-\mathrm{C}$.

\section{Paratypes}

Slide 27227-3; MGUH no. 33446, MC $21.3 \times 105.1$, EF reference K20/3. IODP Leg 342, Site U1411; Sample 342-U1411B-6H-4, 24-26 cm; depth: 43.64 m b.s.f. Offshore Newfoundland. Earliest Chattian. Slide is curated at the Geological Museum of the University of Copenhagen. Plate 1F.

Slide P-76119; MGUH no. 33447; MC $35.5 \times 110.3$, EF reference E36/3. DSDP Site 112, Sample 112-5-1, 23-30 cm. Western North Atlantic. Mid-Oligocene, Plate 1G.

\section{Description}

A fusiform peridiniacean species with apex and antapex, each having a single short and bluntly rounded horn. The cyst is long, wide, and cornucavate. The endocyst is ellipsoidal and has a smooth wall. The periphragm is nearly smooth to faintly or conspicuously ornamented with a microrugulate pattern that may include discrete and partially fused granules and may develop into an incomplete microreticulation.
The endophragm and periphragm are appressed except at the horns. The horns are rounded to bulbous in shape. A small tapering antapical or apical protuberance up to $7 \mu \mathrm{m}$ long may occur at the termination of a horn (marked by an arrow in Plate $1 \mathrm{E}$ and $\mathrm{H}$ ). Horns are approximately equal in length, and each is generally less than $30 \%$ of the endocyst length. When the periphragm is nearly smooth, the tabulation is expressed only by the archeopyle. On more coarsely ornamented specimens, the tabulation may be expressed by the cingulum and/or plates 1a, 3a, 3-5", and/or 1-2"'t' in addition to the archeopyle. The archeopyle is intercalary type I (2a), isodeltaform (operculum free). The periarcheopyle is of similar size or slightly larger than the endoarcheopyle. The adcingular margin of the periarcheopyle is up to $\sim 1.5 \mu \mathrm{m}$ higher than that of the endoarcheopyle (Plate 1F).

\section{Dimensions}

Holotype: endocyst length $87 \mu \mathrm{m}$; pericyst length $122 \mu \mathrm{m}$; width $57 \mu \mathrm{m}$; apical horn length $20 \mu \mathrm{m}$; antapical horn length $20 \mu \mathrm{m}$. Range $(n=12)$ : endocyst length $75-98 \mu \mathrm{m}$ (mean $85.2 \mu \mathrm{m}$ ); pericyst length $100-150 \mu \mathrm{m}$ (mean $120.2 \mu \mathrm{m}$ ); width $52-65 \mu \mathrm{m}$ (mean $57.5 \mu \mathrm{m}$ ); apical horn length 12$25 \mu \mathrm{m}$ (mean $19.4 \mu \mathrm{m}$ ); antapical horn length $15-30 \mu \mathrm{m}$ (mean $20.2 \mu \mathrm{m}$ ). 

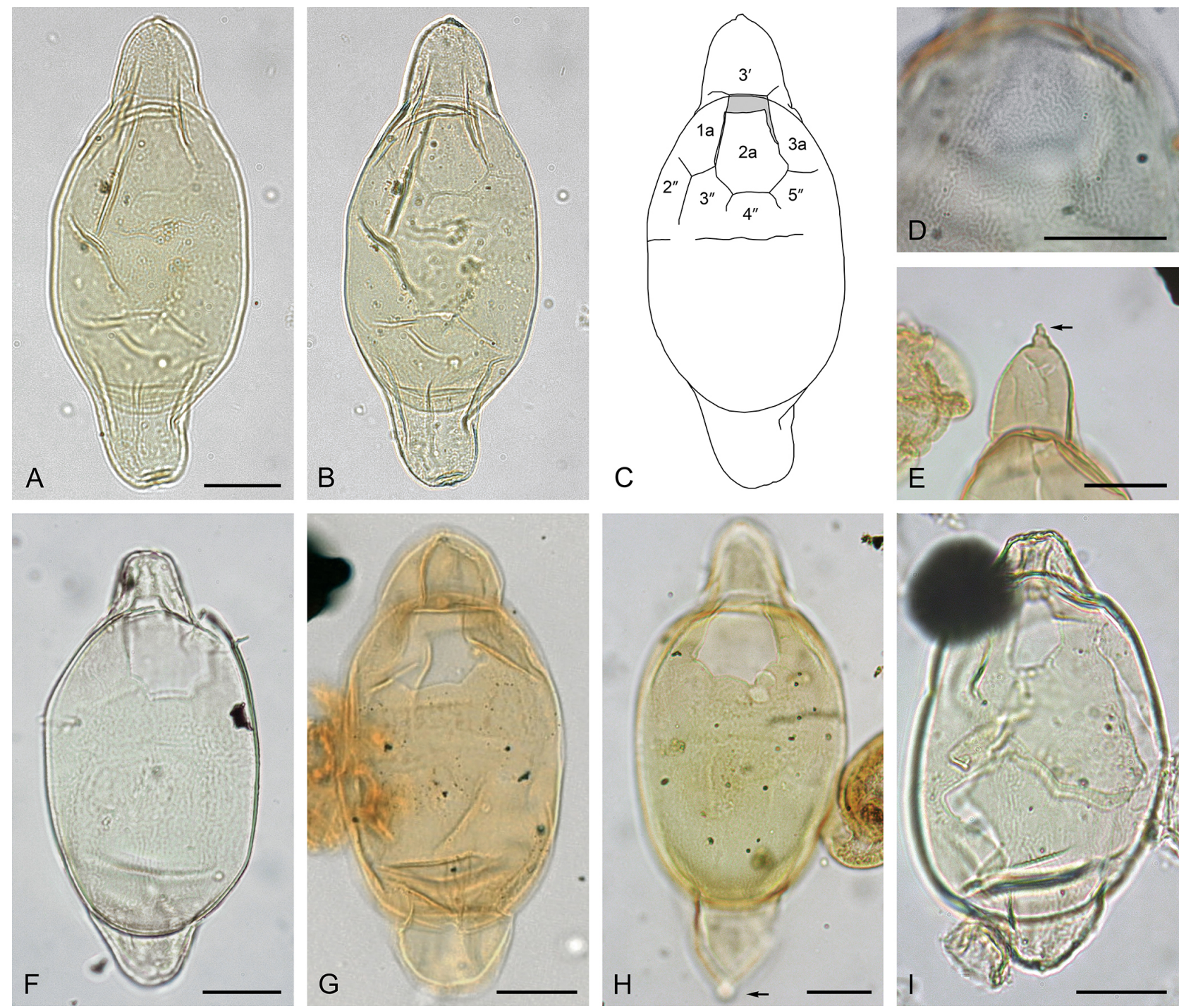

Plate 1. A scale bar of $20 \mu \mathrm{m}$ applies to all figures except where stated. (A-I) Svalbardella clausii sp. nov. (A-C) Holotype, (A) ventral surface and (B) dorsal surface; Nini-1 well; depth: 1100.0 mbKB; slide K158L-2; MGUH no. 33445; MC: 23 × 98.2; EF: S23/1; cyst length: $122 \mu \mathrm{m}$; (C) tracing of (B) showing expression of tabulation around the archeopyle (operculum partially detached). (D) DSDP Site 112, Sample 112-5-1, 23-30 cm; slide P-76119; MC: 36.4 × 102; EF: O36/2; (E) DSDP Site 112, Sample 112-5-1, 23-30 cm; slide P-76119; MC: 35 × 102.2 EF: O35/1; (F) Paratype, dorsal surface; IODP Site U1411, Sample 342-U1411B-6H-4, 24-26 cm; depth: 43.64 m b.s.f.; slide 27227-3; MGUH no. 33446, MC: $21.3 \times 105.1$; EF: K20/3; cyst length $112 \mu \mathrm{m}$. (G) Paratype DSDP Site 112, dorsal surface, Sample 112-5-1, 23-30 cm; slide P-76119; MGUH no. 33447; MC: $35.5 \times 110.3$; EF: E36/3; cyst length: $115 \mu$ m. (H) Dorsal surface; DSDP Site 112, Sample 112-5-1, 23-30 cm; slide P-76119; MC: $43 \times 97$ EF: T44/1; cyst length $150 \mu \mathrm{m}$. (I) Dorsal surface; IODP Site U1406, Sample 342-U1406B-17H-4, 76-79 cm; depth: 148.76 m b.s.f.; slide 25266-4; MC: $28.7 \times 103.3$; EF: M28/4; cyst length $100 \mu$ m.

\section{Occurrence}

North Sea basin, Alma-1x and Nini-1 wells; western North Atlantic, Hole IODP U1411B (40.6 and 53.1 metres below sea floor, mb.s.f.; Chron C9n), Hole IODP U1406B (148.76 m b.s.f.; Chron C9n), and Hole IODP 1406C (141.31 and 142.82 m b.s.f.; Chron C9n); Labrador Sea, DSDP Sites 112 and 119.

\section{Age}

Existing records suggest that Svalbardella clausii sp. nov. is limited to a narrow range within the mid-Oligocene. The widest and least specific range for Svalbardella clausii sp. nov. is provided by Damassa et al. (1990; as Palaeocystodinium sp. 2), who observed the lowest occurrence (LO) somewhere in NP24 and the highest occurrence (HO) somewhere within NP25 (a maximum time span between approximately 29.5 and $23 \mathrm{Ma}$; Vandenberghe et al., 2012) in the 
western North Atlantic. In the two studied sites from offshore Newfoundland, IODP Sites U1411 (Hole U1411B, 40.6 and $53.1 \mathrm{~m}$ b.s.f.; Chron C9n) and U1406 (Hole U1406B, 148.76 m b.s.f.; Hole U1406C, 141.31 and $142.82 \mathrm{~m}$ b.s.f.), the species ranges within Chron C9n (Site U1411 magnetostratigraphy after Norris et al., 2014; Site U1406 magnetostratigraphy after van Peer et al., 2017) and thus is of earliest Chattian age.

In the North Sea, this species is reported in two industrial wells (Nini-1 and Alma-1x), from which only ditch cuttings are available. Due to the high risk of caving we focus here on the highest occurrences (HOs). The HO of Svalbardella clausii sp. nov. is observed either at the Rupelian/Chattian boundary (Schiøler, 2005) or in the lowermost Chattian (Śliwińska et al., 2010, 2014a). In both wells, the HO of Svalbardella clausii sp. nov. occurs below the HO of Licracysta? semicirculata (Schiøler, 2005; Śliwińska et al., 2010), which in the North Sea basin is a well-established lowermost Chattian marker occurring within Chron C8r (Śliwińska et al., 2012). The range of Svalbardella clausii sp. nov. is synchronous with the mid-Oligocene Svalbardella cooksoniae occurrence interval, which in the Nini-1 well can be correlated with the uppermost NP 24 zone to lowermost NP25 zone (Śliwińska et al., 2014a).

\section{Comparison}

Svalbardella partimtabulata is significantly more slender, has a smaller endocyst, and relatively longer horns, with the antapical horn being significantly longer than the apical horn. Svalbardella cooksoniae has a slightly longer but significantly narrower endocyst and longer and more conical horns in contrast with the short, almost bulbous horns in Svalbardella clausii. Palaeocystodinium obesum is also broad and has very short horns, but they are pointed and slightly smaller in size. However, forms transitional between Palaeocystodinium obesum and Svalbardella clausii sp. nov. (Plate 5D) have been observed in the lower Chattian in the western North Atlantic (e.g. IODP Hole U1406B, Sample 342-U1406B-17-4; 76-79 cm).

\section{Svalbardella kareniae sp. nov.}

Plate 2A-E and H-J

1972 Palaeocystodinium golzowense auct. non Alberti, 1961; Benedek, pl. 3, fig. 7.

1976 Svalbardella (Palaeocystodinium) spp.; Manum, pl. 5, fig. 1 only.

1989 Palaeocystodinium sp. 2; Manum et al., pl. 19, fig. 7.

2005 Palaeocystodinium sp. 1 of Manum et al., 1989; Schiøler, pl. 10, fig. 1

2012 Palaeocystodinium sp. 1; Śliwińska et al., pl. II, fig. 7.

\section{Derivation of name}

After Karen Dybkjær, the PhD co-supervisor of Kasia K. Śliwińska, for her important contributions to the study of Jurassic and Miocene dinoflagellate cysts.

\section{Diagnosis}

A species of Svalbardella with a short and blunt apical horn and long and pointed antapical horn. The periphragm has a smooth to finely ornamented surface; the endophragm is smooth and slightly thicker than the periphragm. The antapical horn is at least 1.5 times as long as the apical horn.

\section{Holotype}

Slide 158L-2, MGUH 33448, EF reference T27/3, MC $27 \times 96.7$. Ditch cutting sample from the Nini-1 well, the eastern North Sea basin; depth: $1100.0 \mathrm{mbKB}$. Lowermost Chattian, from the uppermost part calcareous nannofossil zone NP24, correlated to Chron C9n (Śliwińska et al., 2010, 2014a). Slide is curated at the Geological Museum of the University of Copenhagen (Plate 2A, B).

\section{Paratype}

Slide 4879iii, PMO 235.064, EF reference M43/3. ODP Leg 104, Hole 643A, Sample 643A-40-1, 55-57 cm; Norwegian Sea; depth: $371.95 \mathrm{~m}$ b.s.f. Early Miocene (Manum et al., 1989). Slide is curated at the Natural History Museum in Oslo, Norway (Plate 2H).

\section{Description}

Peridiniacean cyst comprising an ellipsoidal endocyst and fusiform pericyst. The pericyst has a single apical and antapical horn. Periphragm and endophragm are closely appressed except at the horns. The periphragm is smooth to irregularly and minutely reticulate. The endophragm is smooth and slightly thicker than periphragm. The apical horn is blunt, and the termination is tapering with a rounded tip. The antapical horn is conical, pointed distally, and at least 1.5 times longer than apical horn. Tabulation expressed by archeopyle alone, which is intercalary type I (2a), isodeltaform (operculum free).

\section{Dimensions}

Holotype: endocyst length $79 \mu \mathrm{m}$; pericyst length $156.5 \mu \mathrm{m}$; width $36 \mu \mathrm{m}$; apical horn length $28.5 \mu \mathrm{m}$; antapical horn length $49 \mu \mathrm{m}$. Range $(n=8)$ : endocyst length 53$79 \mu \mathrm{m}$ (mean $69.6 \mu \mathrm{m}$ ); pericyst length $115-166 \mu \mathrm{m}$ (mean $148.4 \mu \mathrm{m}$ ); width 28-36.5 $\mu \mathrm{m}$ (mean $33.0 \mu \mathrm{m}$ ); apical horn length 14-34 $\mu \mathrm{m}$ (mean $26.2 \mu \mathrm{m}$ ); antapical horn length 34$66 \mu \mathrm{m}$ (mean $53.8 \mu \mathrm{m})$. 

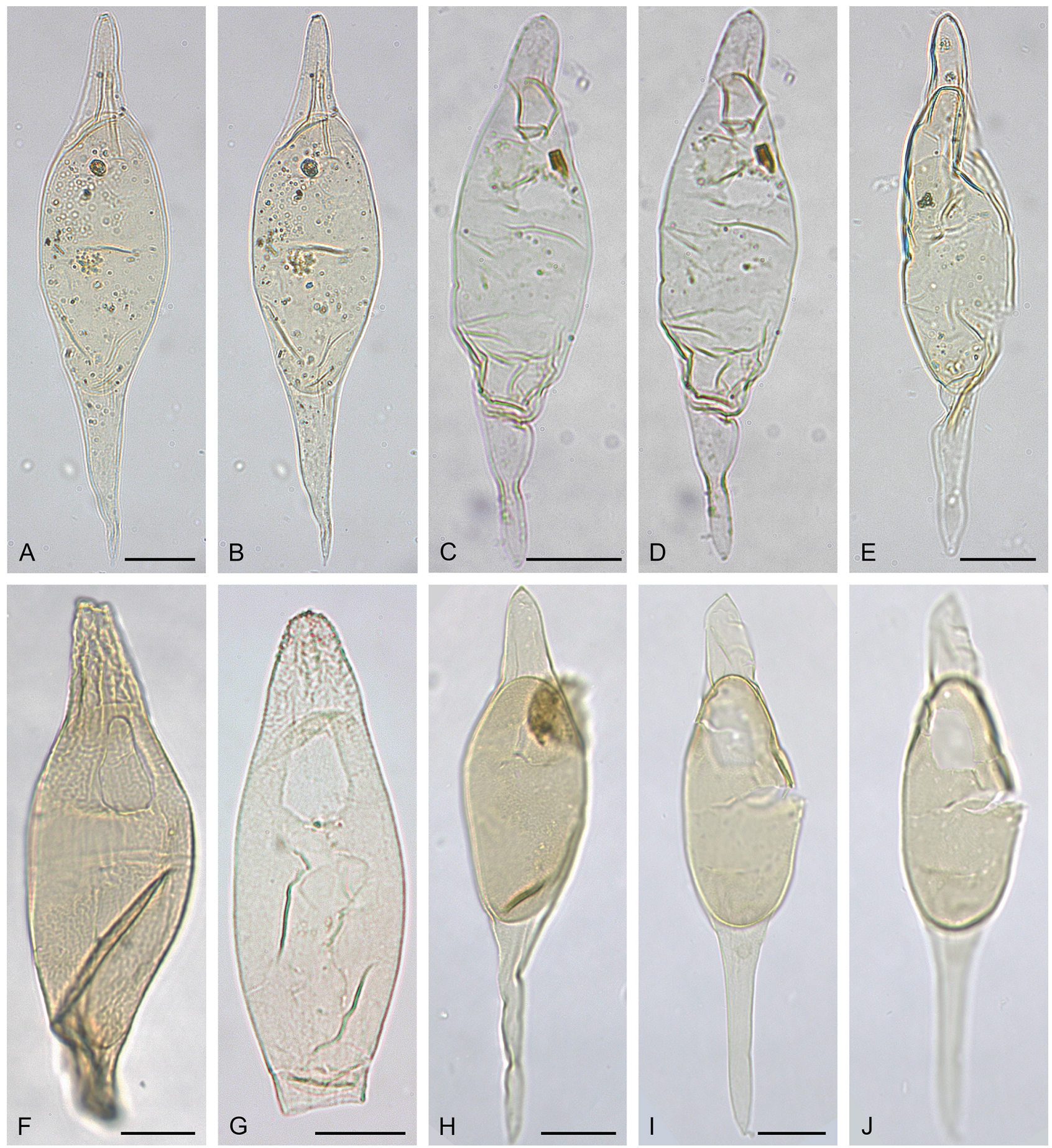

Plate 2. (A-E) Svalbardella kareniae sp. nov. (A-B) Holotype, (A) dorsal surface and (B) ventral surface; Nini-1; depth: $1100 \mathrm{~m}$; slide 158L-2; MGUH 33448; MC: $27 \times 96.7$; EF: T27/3; cyst length: $156.5 \mu \mathrm{m}$. (C) Ventral surface and (D) dorsal surface; Harre-1 borehole; depth: $105.25 \mathrm{~m}$; slide K94F-1; EF: S53/0; cyst length: $115 \mu \mathrm{m}$ (the same specimen as photographed in Śliwińska et al., 2012; see their pl. 2.7). (E) Archeopyle is seen to the right; the Hesselbjerg outcrop section, level $-11.0 \mathrm{~m}$, slide 171K-1; MC: $25 \times 99$; EF: R25/1; cyst length: $143.5 \mu \mathrm{m}$. (F-G) Svalbardella cooksoniae Manum, 1960. (F) Dorsal surface with tabulation around the cingulum; ODP Site 643, Sample 643A-50-1, 30-32 cm; depth: 468.40 m b.s.f.; slide 4668iv; EF: O37/3; cyst length: $123.2 \mu$ m. (G) Dorsal surface with no tabulation in the cingular area; 11/10-1 well; depth: 823.0 m b.s.f.; MC: $47.5 \times 104.5$; EF: L48/3; (H-J) Svalbardella kareniae sp. nov. (H) Paratype, dorsal surface, ODP Site 643, Sample 643A-40-1, 55-57 cm; depth: 371.95 m b.s.f.; slide 4879iii; PMO: 235.064; EF: M43/3; cyst length: $161.7 \mu \mathrm{m}$. (I) Ventral surface, (J) dorsal surface; ODP Site 643, Sample 643A-40-1, 55-57 cm; depth: 371.95 m b.s.f.; slide 4879iii; EF: K42/0; cyst length: $161.5 \mu \mathrm{m}$. 


\section{Occurrence}

Norwegian Sea, DSDP Leg 38, Hole 338, Sample 338-26-5, 100-102 cm - as "Svalbardella (Palaeocystodinium) spp." in Manum, 1976, pl. 5, fig. 1 only; Norwegian Sea, ODP Leg 104, Hole 643A, Samples 42-1, 19-21 cm (390.89 m b.s.f.), to $37-3,20-22 \mathrm{~cm}$ (345.50 m b.s.f.), inclusive (as Palaeocystodinium sp. 2 in Manum et al., 1989); the North Sea, Alma-1x well, recorded in ditch cutting samples between 1844.0 and $1725.2 \mathrm{~m}$ (as Palaeocystodinium sp. 1 of Manum et al., 1989, in Schiøler, 2005); onshore Denmark in the Viborg-1 borehole between 164.0 and $133.5 \mathrm{~m}$, in the Harre1 borehole between 113.75 and $70.75 \mathrm{~m}$, and in the Hesselbjerg outcrop section from -9.0 to $7.5 \mathrm{~m}$ (as Palaeocystodinium sp. 1 in Śliwińska et al., 2012). In Denmark the sediments yielding Svalbardella kareniae sp. nov. belong to the Branden Clay unit (see Śliwińska et al., 2012).

\section{Age}

In the Norwegian Sea the species is observed in two Holes. In DSDP Hole 338 in Sample 338-26-5, 100-102 cm, the sample was initially dated as Late Eocene (Manum, 1976). However, more recently Eldrett and Harding (2009) suggested an Early Oligocene age for the sample. In another hole, ODP Hole 643A, the species is recorded in the Early Miocene (A. granosa zone of Manum et al., 1989, above the HO of Chiropteridium spp.; Manum et al., 1989; Śliwińska et al., $2014 b$ ). In the North Sea, the species is observed in the Rupelian and Chattian stages of the Oligocene (Schiøler, 2005; Śliwińska et al., 2012).

\section{Comparison}

Svalbardella partimbulata also has a short apical and a long antapical horn, but faint sutural lines or low ridges on the periphragm surface partially delimit the tabulation. Also the apical horn tends to be relatively longer than for Svalbardella kareniae sp. nov. and the central body shorter relative to the total length. Svalbardella cooksoniae has coarser ornamentation on the periphragm and wider horns with apical and antapical horns being of similar lengths. Svalbardella clausii sp. nov. has significantly shorter horns that are both rounded and equal in length. The shape of the antapical horn in Svalbardella kareniae sp. nov. resembles that in Palaeocystodinium golzowense.
Svalbardella sp. cf. S. partimtabulata HeilmannClausen and Van Simaeys, 2005

Plate $3 \mathrm{~A}-\mathrm{F}$

\section{Description}

The periphragm is about $0.3 \mu \mathrm{m}$ thick and has an outer surface with low microrugulae with interspersed granules, in places forming a discontinuous microreticulum. The endophragm is about $0.6 \mu \mathrm{m}$ thick and smooth. Archeopyle intercalary, type I (2a), periarcheopyle slightly larger than endoarcheopyle, its adcingular margin overlapping that of the endoarcheopyle by about $2 \mu \mathrm{m}$ (operculum free). The tabulation is also indicated by sutural features on the hypocyst expressed as rudimentary septa.

\section{Dimensions}

Endocyst length: $62 \mu \mathrm{m}$; pericyst length: $151 \mu \mathrm{m}$; width: $22 \mu \mathrm{m}$; apical horn length: $31 \mu \mathrm{m}$; antapical horn length: $61 \mu \mathrm{m}$. One specimen measured.

\section{Occurrence}

A single specimen, slide No. MCP 2276 (5), Renardodden, Spitsbergen. The slide is curated at Brock University.

Age

The sample is dated palynologically as Late Eocene or Early Oligocene (Head, 1984).

\section{Remarks}

This specimen is most similar to Svalbardella partimtabulata but has a relatively longer endocyst and relatively shorter apical horn. Additionally, the boundary between the postcingular and antapical plate series (marked by an arrow in Plate 3A, B) occurs at the approximate level of the endocyst antapex, whereas in Svalbardella partimtabulata it is much lower. This may be a consequence of the relatively longer endocyst in the Spitsbergen specimen. 

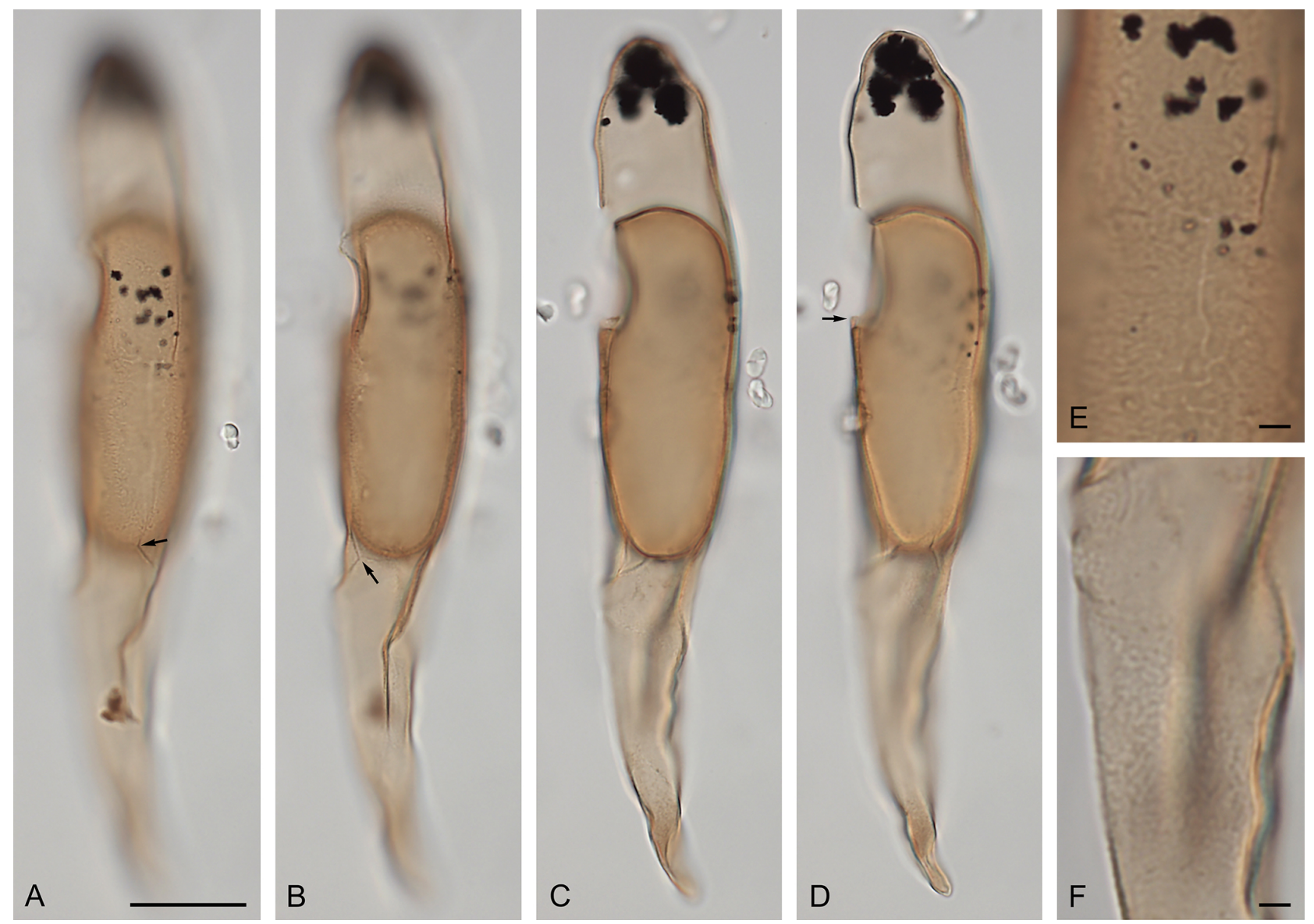

Plate 3. (A-F) Svalbardella sp. cf. S. partimtabulata Heilmann-Clausen and Van Simaeys, 2005. Right lateral view (A-D) at upper- through mid-foci, with margin between postcingular and antapical plate series shown by arrows (A, B), adcingular margin of periarcheopyle overlapping that of endoarcheopyle shown by arrow (D), and detail of wall surface on central body (E) and antapical horn (F); Renardodden, Spitsbergen; slide MCP 2276(5); EF: M41/2; cyst length: $151 \mu \mathrm{m}$. Scale bar $=2 \mu \mathrm{m}$ in (E), (F).

Genus Palaeocystodinium Alberti, 1961

\section{Type}

Alberti, 1961, pl. 7, fig. 12, as Palaeocystodinium golzowense.

Palaeocystodinium obesum Fensome et al., 2009, emend.

Plates $4 \mathrm{~A}-\mathrm{H}$ and $5 \mathrm{~A}-\mathrm{C}$

1972 Svalbardella cf. granulata; Benedek, p. 14, pl. 3, fig. $5 \mathrm{a}, \mathrm{b}$.

1990 Palaeocystodinium sp. 1; Damassa et al., fig. 5 G, J. 1996 Svalbardella sp. 1; Poulsen et al., pl. 3, fig. 13.

2009 Palaeocystodinium obesum Fensome et al., p. 50, pl. 8, figs. j-1.

\section{Original description}

A species of Palaeocystodinium with relatively short but pointed horns, a smooth periphragm, and a broad endocyst. Bicavate, with pericoels restricted to polar regions; wall layers appressed laterally (Fensome et al., 2009, p. 50).

\section{Emended diagnosis}

A species of Palaeocystodinium with short, pointed horns, a nearly smooth to microrugulate-microreticulate periphragm and a broad endocyst. Faint tabulation, including cingulum, may be expressed. Cornucavate, with pericoels restricted to polar regions; wall layers appressed laterally. The $2 \mathrm{a} / 5^{\prime \prime}$ margin is considerably longer than the $2 \mathrm{a} / 3^{\prime \prime}$ margin.

\section{Emended description}

Peridiniacean cyst comprising broad ellipsoidal endocyst and short, pointed horns. Periphragm has a nearly smooth to finely ornamented periphragm. This fine ornament varies 

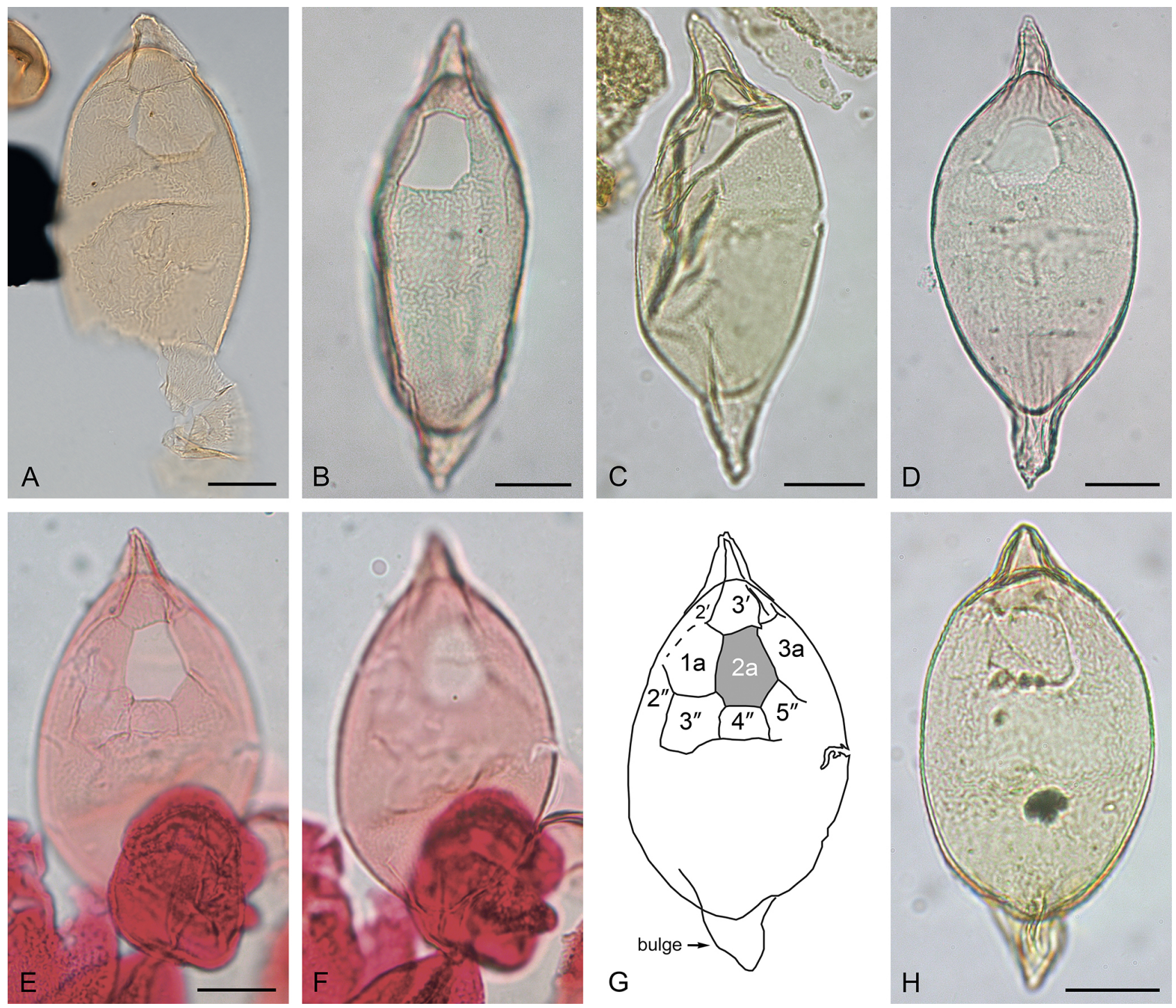

Plate 4. (A-H) Palaeocystodinium obesum Fensome et al., 2009, emend. (A) Dorsal surface; cingulum is clearly seen; IODP Site U1411, Sample 342-U1411B-4-6, 24-26 cm; depth: 27.64 m b.s.f.; slide 25289-5; MC: $26.4 \times 103.3$; EF: M26/4. (B) Dorsal surface; IODP Site U1411, Sample U1411B-5H-6, 24-26 cm; depth: 37.14 m b.s.f.; slide 27226-3; MC: 23.7× 105; EF: K23/4; cyst length: 112.5 $\mu$ m. (C) Ventral surface; Nini-1; depth: 1040 m; slide 160L-1, MC: $51.2 \times 106.6$, EF: J52/4; cyst length: $117 \mu$ m. (D) Dorsal surface; Site U1411, Sample 1411B-5H-6, 24-26 cm; depth: 37.14 m b.s.f.; slide 27226-3, MC: $\times 110$; EF: F34/1; cyst length: $129 \mu$ m. (E) Dorsal surface; tabulation visible around the archeopyle; DSDP Site 338, Sample 338-21-1, slide P-76932-A01; MC: $40.3 \times 98.3$; EF: S40/2; cyst length: $112 \mu$ m. (F) Same specimen as shown in (E); ventral surface. (G) Tracing of dorsal surface of specimen shown in (E) and (F) with tabulation visible around the archeopyle. (H) Dorsal surface; IODP Site U1406, Sample 342-U406C-16-6, 76-78 cm; depth: 142.85 m b.s.f.; slide 25282-3; MC: $47.3 \times 99.6$; EF: Q48/3; cyst length: $96 \mu \mathrm{m}$.

from a complete microreticulation (apparently present on the holotype, Plate 5A) to a microrugulate pattern that forms an incomplete microreticulation (Plate $4 \mathrm{~A})$. When the periphragm is smooth or faintly ornamented, the tabulation is expressed by the archeopyle only. On more prominently ornamented specimens, tabulation may be expressed also by a cingulum, and on some specimens plates $2-3^{\prime}, 1 \mathrm{a}, 3 \mathrm{a}, 2-5^{\prime \prime}$, and/or 1-2'"'l' are distinguishable (Plate $4 \mathrm{E}-\mathrm{G}$ ) in addition to the archeopyle. The $2 \mathrm{a} / 3^{\prime}$ margin is relatively long, and the
$2 \mathrm{a} / 5^{\prime \prime}$ margin is considerably longer than the $2 \mathrm{a} / 3^{\prime \prime}$ margin (Plate 4A, B, D-H). Expression of tabulation is, however, a variable feature. The antapical horn may be asymmetrical owing to a "bulge", as shown in Plate 4E-H (this study), in Benedek (1972, pl. 3 fig. 5), in Damassa et al. (1990, fig. 5J), and on the holotype itself (Plate 5A, also in Fensome et al., 2009, pl. 8, fig. 1). Archeopyle intercalary, type I (2a), isodeltaform (operculum free). 

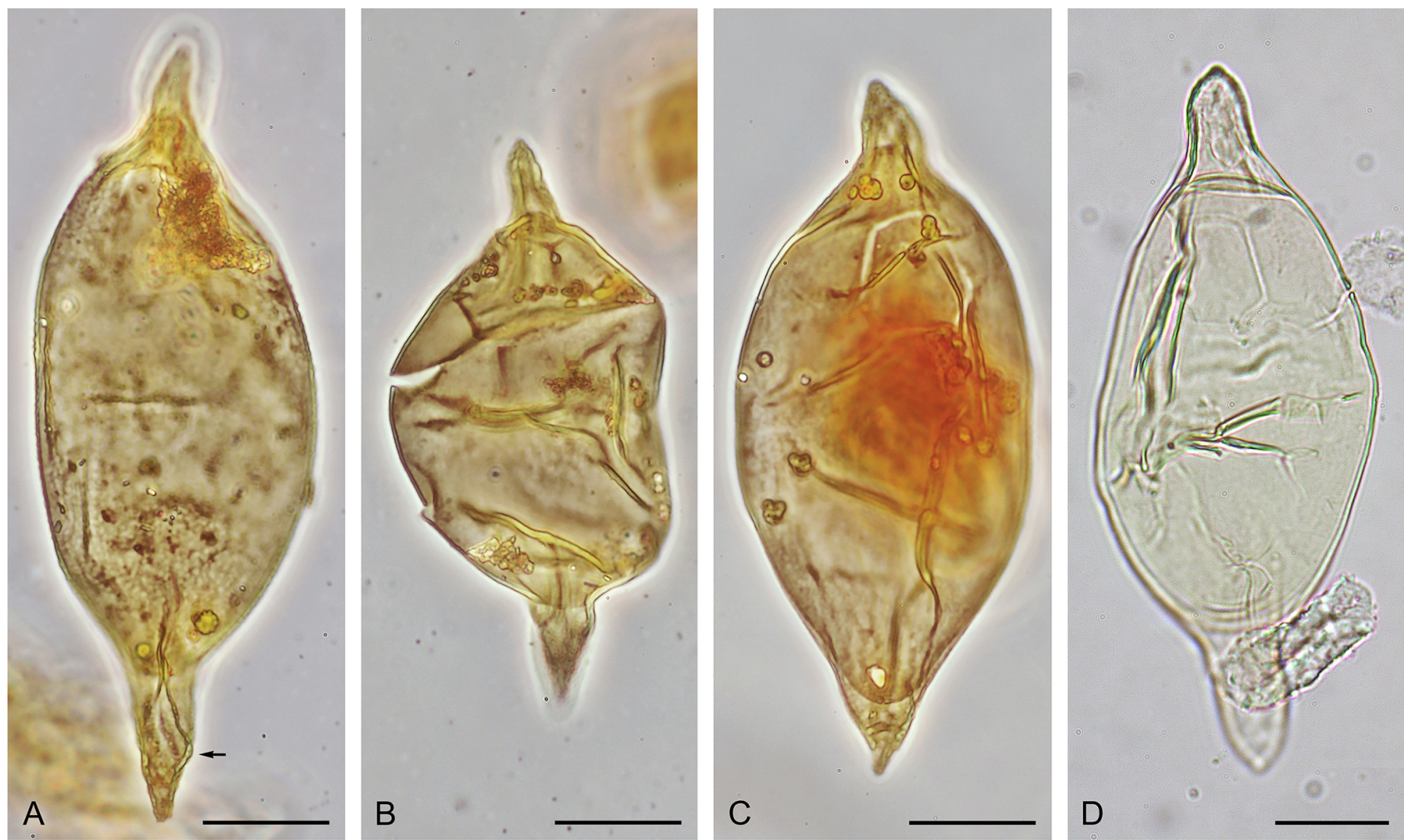

Plate 5. (A-C) Palaeocystodinium obesum Fensome et al., 2009, emend. (A) Holotype, with microreticulate surface ornamentation and distinctive bulge on antapical horn indicated by arrow; sidewall core sample at $751.6 \mathrm{~m}$ (2466 ft) in Onondaga E-84 well, Scotian Margin off eastern Canada; GSC type collection no. 130270; sample P37515; slide 01; EF: O49/2; total length: $129 \mu \mathrm{m}$ (photo supplied by Robert A. Fensome; see Fensome et al., 2009, pl. 8, fig. 1). (B) Topotype specimen; sidewall core sample at $751.6 \mathrm{~m}$ ( $2466 \mathrm{ft})$ in Onondaga E-84 well, Scotian Margin off eastern Canada; GSC type collection no. 130269; sample P37515; slide 01; EF: L51/0; total length: 94 4m (photo supplied by Robert A. Fensome; see Fensome et al., 2009, pl. 8, fig. k). (C) Topotype specimen; sidewall core sample at 751.6 m (2466 ft) in Onondaga E-84 well, Scotian Margin off eastern Canada; GSC type collection no. 130268; sample P37515; slide 01; EF: K40/4; total length: $115 \mu \mathrm{m}$ (photo supplied by Robert A. Fensome; see Fensome et al., 2009, pl. 8, fig. j). (D) Specimen transitional between Svalbardella clausii sp. nov. and Palaeocystodinium obesum; dorsal surface; IODP Site U1406, Sample 342-U1406B-17H-4, 76-79 cm; depth: 148.76 m b.s.f.; slide 25266-4; MC: $55 \times 100.2$; EF: Q56/1; total length: $117 \mu \mathrm{m}$. Figures (A)-(C) are reprinted from "Late Cretaceous and Cenozoic fossil dinoflagellates and other palynomorphs from the Scotian Margin, offshore eastern Canada" by Fensome, R. A., Williams, G. L., and MacRae, R. A.; Journal of Systematic Palaeontology, copyright 2009 @ The Natural History Museum, reprinted by permission of lnforma UK Limited, trading as Taylor \& Francis Group, https://www.tandfonline.com on behalf of The Natural History Museum.

\section{Dimensions}

Holotype: endocyst length $92 \mu \mathrm{m}$; pericyst length $129 \mu \mathrm{m}$, overall width $45 \mu \mathrm{m}$ (Fensome et al., 2009). Range (this study): endocyst length 69-104 $\mu \mathrm{m}$ (mean $81.9 \mu \mathrm{m})$; pericyst length $92-137 \mu \mathrm{m}$ (mean $110.8 \mu \mathrm{m})$; width $37-56 \mu \mathrm{m}$ (mean $49.3 \mu \mathrm{m})$; apical horn length $8-19 \mu \mathrm{m}$ (mean $13.9 \mu \mathrm{m})$; antapical horn length 9-20 $\mu \mathrm{m}$ (mean $16.1 \mu \mathrm{m}$ ). Twelve specimens from DSDP Site 112 and IODP Hole 1411B, showing slightly wider size ranges than reported by Fensome et al. (2009) based on three specimens.

\section{Occurrence}

In addition to the Scotian Margin, which is the type locality, this species is present off Newfoundland (IODP Hole
U1411B), the Greenland Sea (ODP Site 908), the Norwegian Sea (DSDP Site 338), and the North Sea (Nini-1) (Damassa et al., 1990; Poulsen et al., 1996; this study).

\section{Age}

On the Scotian Margin off Canada, from where the holotype is described, the $\mathrm{HO}$ is in the upper Rupelian (Fensome et al., 2009). In the North Atlantic Palaeocystodinium obesum (as Palaeocystodinium sp. 1) is reported from NP19/20 to NP24, suggesting a range from Priabonian to mid-Oligocene (Damassa et al., 1990). Off Newfoundland, this species ranges from Chron $\mathrm{C} 12 \mathrm{r}$ to Chron $\mathrm{C} 9 \mathrm{n}$, although deposits older than earliest Oligocene were not investigated (this study). In the Greenland Sea and the North Sea, it is observed in the Chattian (Poulsen et al., 1996; this study). 


\section{Remarks}

The holotype bears faint lineations on the hypocyst running from the central body down to the antapical horn that might represent tabulation. Re-examination of the specimen will be needed to confirm this. This species is emended to include specimens having a microrugulate-microreticulate periphragm and traces of tabulation in addition to the archeopyle.

\section{Discussion}

The two new species, Svalbardella clausii sp. nov. and Svalbardella kareniae sp. nov., widen the morphological diversity of the genus Svalbardella emend., which until, now has been limited to two formally described species: Svalbardella cooksoniae Manum, 1960, and Svalbardella partimtabulata Heilmann-Clausen and Van Simaeys, 2005.

Our new observations from the Oligocene succession of the North Sea and offshore Newfoundland require the emendation of Palaeocystodinium obesum Fensome et al., 2009, which now includes forms with fine ornament as well as traces of tabulation in addition to the archeopyle. This study also confirms that within both Svalbardella and Palaeocystodinium, as presently conceived, tabulation is expressed variably, even within individual species (e.g. Svalbardella clausii and Palaeocystodinium obesum) and may be related to the degree of ornamentation on the periphragm.

Svalbardella kareniae provides a link between the genera Svalbardella and Palaeocystodinium. If a specimen of Svalbardella kareniae broke along the cingulum, its antapical horn would easily be confused with that of Palaeocystodinium golzowense. The presence of forms transitional between Palaeocystodinium obesum and Svalbardella clausii (Plate 5D) provides an additional link. This emphasizes the close morphological similarity between Svalbardella and Palaeocystodinium and implies a close phylogenetic relationship. However, we consider it premature to synonymize these genera while the stratigraphic ranges and fine morphological details of many species are incompletely known. Future studies incorporating both light and scanning electron microscopy that document the fine ornamentation of the periphragm, details of the tabulation where exhibited, and morphology of both the endo- and periarcheopyle, augmented by morphometric studies documenting intraspecific variability - and all accomplished using finely age-calibrated samples will be needed to understand fully the relationship between these two genera over their ranges.

Svalbardella clausii is observed in the northern high and middle latitudes in a very narrow time interval spanning the NP24-NP25 boundary and Chron C9n. The species has a wide spatial distribution across the North Atlantic (North Sea, western North Atlantic, and Labrador Sea). The horizon containing Svalbardella clausii is therefore a prime marker for the lower Chattian succession in this region. The range of this species overlaps with the timing of the reappearance of Svalbardella cooksoniae and spans the Oi-2b cooling maximum (Śliwińska et al., 2010; Van Simaeys et al., 2005). Therefore, the presence of Svalbardella clausii may be related to an establishment of colder surface waters associated with the cooling. This species notably appears not to have penetrated into the Norwegian-Greenland Sea.

Svalbardella kareniae appears in narrow but diachronous intervals. In the North Sea basin this species is observed in the Oligocene, whereas in the Norwegian Sea it is recorded either from the Lower Oligocene (DSDP Hole 338) or Lower Miocene (ODP Hole 643A). The Branden Clay unit onshore Denmark, where Svalbardella kareniae is present, represents a short interval during the Oligocene when conditions were more fully marine (Friis, 1994). The Branden Clay is the only unit in the Danish Oligocene succession that yields wellpreserved specimens of the planktonic foraminiferal genus Globigerina (Ulleberg, 1987). In DSDP Hole 338, the appearance of Svalbardella kareniae coincides with a change to open marine/oceanic conditions, as suggested by the dinoflagellate cyst assemblage (Eldrett and Harding, 2009). In ODP Hole 643A, the appearance of Svalbardella kareniae similarly corresponds to a change to more open marine conditions, as suggested by the biomarker record and dinoflagellate cyst assemblages (Śliwińska et al., 2010, 2014a). All these observations imply that Svalbardella kareniae was sensitive to changes in the palaeoenvironment, presumably favouring more open marine conditions.

\section{Conclusions}

Svalbardella clausii sp. nov. and Svalbardella kareniae sp. nov. are formally described herein, requiring the emendation of the genus Svalbardella, and Svalbardella sp. cf. S. partimtabulata Heilmann-Clausen and Van Simaeys, 2005, is reported from Spitsbergen. This study also emends Palaeocystodinium obesum Fensome et al., 2009, which now includes specimens with a finely ornamented periphragm and traces of tabulation in addition to the archeopyle.

The distribution of Svalbardella clausii appears to reflect an affinity for colder sea surface temperatures, and that of Svalbardella kareniae reflects open marine conditions. The narrow and synchronous range of Svalbardella clausii makes it an excellent mid-Oligocene marker for the North Atlantic region.

The morphology of Svalbardella kareniae and those forms transitional between Palaeocystodinium obesum and Svalbardella clausii illustrate the close phylogenetic relationship between Svalbardella and Palaeocystodinium, these two genera being separated on the presence of bluntly rounded versus pointed terminations of the horns. This study also clearly illustrates that surface ornamentation and the tabulation it may express are variable features within both genera. 
Data availability. Palynological slides are stored at the Natural History Museum in Oslo, Norway (643A), GEUS (Nini-1, Harre1 U1411, U1406), the Norwegian Petroleum Directorate (11/10-1 well), and Brock University (Renardodden).

Author contributions. KKŚ designed the project and carried out the analysis (Harre-1, Hesselbjerg, Nini-1, 11/10-1, Site U1411, Site U1406, Site 112, Site 338, and Hole 643A) together with MJH (Renardodden). Both authors wrote the paper.

Competing interests. The authors declare that they have no conflict of interest.

Acknowledgements. This research was conducted on samples provided by the International Ocean Discovery Program (IODP), which includes its predecessors, the International Ocean Drilling Program (IODP), Ocean Drilling Program (ODP), and Deep Sea Drilling Project (DSDP). Kasia K. Śliwińska is most grateful to the late Svein B. Manum for inspiring discussions and sharing his view on the morphology of Svalbardella cooksoniae, Franz-Josef Lindemann (Natural History Museum in Oslo) for his assistance during her visit to the Museum, and Sarah Damassa for sharing her slides from DSDP Site 112 and a slide from DSDP 338. Annette Ryge and Dorthe Samuelsen (GEUS) are kindly acknowledged for preparing palynological slides from Sites U1406 and U1411. Robert Williams (NPD) took a photo shown on Plate 4A. We are grateful to the journal reviewers, Laurent Londeix and Robert A. Fensome. Further, we thank Robert A. Fensome for providing original photographs of Palaeocystodinium obesum which are illustrated here (Plate 5AC). The COVID-19 pandemic prevented us from personally reexamining type specimens.

Financial support. This research has been supported by the Danish Council for Independent Research (grant no. 11-107497 to Kasia K. Śliwińska) and the Natural Sciences and Engineering Research Council of Canada (to Martin J. Head).

Review statement. This paper was edited by Luke Mander and reviewed by Laurent Londeix and Robert A. Fensome.

\section{References}

Alberti, G.: Zur Kenntnis mesozoischer und alttertiärer Dinoflagellaten und Hystrichosphaerideen von Nord- und Mitteldeutschland sowie einigen anderen europäischen Gebieten, Palaeontogr. Abt. A, 116, 1-58, 1961.

Barss, M. S., Bujak, J. P., and Williams, G. L.: Palynological zonation and correlation of sixty-seven wells, eastern Canada, Geological Survey of Canada Paper, Hull, Quebec, 78-24, 1-117, 1979.

Benedek, P. N.: Phytoplanktonten aus dem Mittel- und Oberoligozän von Tönisberg (Niederrheingebiet), Palaeontographica, Abteilung B, 137, 1-71, pl. 1-16, 1972.
Birkenmajer, K., Gedl, P., and Worobiec, E.: Dinoflagellate cyst and spore-pollen spectra from the Lower Oligocene Krabbedalen Formation at Kap Brewster, East Greenland, Pol. Polar Res., 31, 103-140, https://doi.org/10.4202/ppres.2010.07, 2010.

Brinkhuis, H., Munsterman, D. K., Sangers, S., Sluijs, A., Warnaar, J., and Williams, G. L.: Late Eocene-Quaternary dinoflagellate cysts from ODP Site 1168, off western Tasmania, in: Proceedings of the Ocean Drilling Program, Scientific Results, Vol. 189, edited by: Exon, N. F., Kennett, J. P., and Malone, M. J., College Station, TX (Ocean Drilling Program), 1-36, https://doi.org/10.2973/odp.proc.sr.189.105.2003, 2003.

Bujak, J. P. and Davies, E. H.: Modern and fossil Peridiniineae. American Association of Stratigraphic Palynologists, Contributions Series, no.13, 203 pp., 12 pl., 1983.

Bütschli, O.: Erster Band. Protozoa, in: Dr. H.G. Bronn's Klassen und Ordnungen des Thier-Reichs, wissenschaftlich dargestellt in Wort und Bild; 865-1088; C.F. Winter'sche Verlagsbuchhandlung, Leipzig and Heidelberg, Germany, 1885.

Clausen, O. R., Śliwińska, K. K., and Gołedowski, B.: Oligocene climate changes controlling forced regression in the eastern North Sea, Mar. Petrol. Geol., 29, 1-14, https://doi.org/10.1016/j.marpetgeo.2011.10.002, 2012.

Coccioni, R., Montanari, A., Bice, D., Brinkhuis, H., Deino, A., Frontalini, F., Lirer, F., Maiorano, P., Monechi, S., Pross, J., Sagnotti, L., Sideri, M., Sprovieri, M., Tateo, F., Rochette, P., Touchard, Y., Van Simaeys, S., and Williams, G. L.: The Global Stratotype Section and Point (GSSP) for the base of the Chattian Stage (Paleogene System, Oligocene Series) at Monte Cagnero, Italy, Episodes, 41, 17-32, https://doi.org/10.18814/epiiugs/2018/v41i1/018003, 2018.

Cookson, I. C.: Microplankton from the Paleocene Pebble Point Formation, south-western Victoria, Proceedings of the Royal Society of Victoria, 78, 137-141, pl. 24-25, 1965.

Damassa, S. P., Goodman, D. K., Kidson, E. J., and Williams, G. L.: Correlation of Paleogene dinoflagellate assemblages to standard nannofossil zonation in North Atlantic DSDP sites, Rev. Palaeobot. Palyno., 65, 331-339, https://doi.org/10.1016/00346667(90)90083-U, 1990.

De Coninck, J.: Organic-walled phytoplankton biostratigraphy of the Eocene-Oligocene transition in the Kallo Borehole and the Rupelian stratotype area (northwestern Belgium), Bulletin de la Société belge de géologie, 105, 171-209, 1996.

Egger, L. M., Śliwińska, K. K., van Peer, T. E., Liebrand, D., Lippert, P. C., Friedrich, O., Wilson, P. A., Norris, R. D., and Pross, J.: Magnetostratigraphically-calibrated dinoflagellate cyst bioevents for the uppermost Eocene to lowermost Miocene of the western North Atlantic (IODP Expedition 342, Paleogene Newfoundland sediment drifts), Rev. Palaeobot. Palyno., 234, 159185, https://doi.org/10.1016/j.revpalbo.2016.08.002, 2016.

Ehrenberg, C. G.: Animalia evertebrata exclusis Insectis. Series prima, in: Symbolae physicae, seu icones et descriptiones Mammalium, Avium, Insectorum et animalia evertebra, quae ex itinere per Africam borealem et Asiam occidentalem studio nova aut illustrata redierunt, edited by: Hemprich, F. G. and Ehrenberg, C. G., 126 pp. (1831), 10 pls (1828), available at https://biodiversitylibrary.org/page/48517135 (last access: 13 August 2020), 1828-1831.

Eidvin, T., Bugge, T., and Smelror, M.: The Molo Formation, deposited by coastal progradation on the inner Mid-Norwegian 
continental shelf, coeval with the Kai Formation to the west and the Utsira Formation in the North Sea, Norsk Geol. Tidsskr., 87, 75-142, https://doi.org/10.1016/j.ultrasmedbio.2010.03.005, 2007.

Eldrett, J. S. and Harding, I. C.: Palynological analyses of Eocene to Oligocene sediments from DSDP Site 338, Outer Vøring Plateau, Mar. Micropaleontol., 73, 226-240, https://doi.org/10.1016/j.marmicro.2009.10.004, 2009.

Eldrett, J. S., Harding, I. C., Firth, J. V., and Roberts, A. P.: Magnetostratigraphic calibration of Eocene-Oligocene dinoflagellate cyst biostratigraphy from the Norwegian-Greenland Sea, Mar. Geol., 204, 91-127, https://doi.org/10.1016/S00253227(03)00357-8, 2004.

Eldrett, J. S., Harding, I. C., Wilshaw, R., and Xuan, C.: A new high northern latitude dinocyst-based magneto-biostratigraphic calibration for the Norwegian-Greenland Sea, Newsl. Stratigr., 52, 435-460, https://doi.org/10.1127/nos/2019/0496, 2019.

Evitt, W. R.: Dinoflagellate studies II. The archeopyle, Stanford University Publications, Geological Sciences, Stanford, CA, 1967.

Fensome, R. A., Taylor, F. J. R., Norris, G., Sarjeant, W. A. S., Wharton, D. I., and Williams, G. L.: A classification of fossil and living dinoflagellates, Micropaleontology Press Special Paper, no. 7, 351 pp., New York, New York, 1993.

Fensome, R. A., Williams, G. L., and MacRae, R. A.: Late Cretaceous and Cenozoic fossil dinoflagellates and other palynomorphs from the Scotian Margin, offshore eastern Canada, J. Syst. Palaeontol., 7, 1-79, https://doi.org/10.1017/ S1477201908002538, 2009.

Firth, J. V.: Upper middle Eocene to Oligocene dinoflagellate biostratigraphy and assemblage variations in Hole 913B, Greenland Sea, in: Proceedings of the Ocean Drilling Program, Scientific Results, Vol. 151, edited by: Thiede, J., Myhre, A. M., Firth, J. V., Johnson, G. L., and Ruddiman, W. F., College Station, TX (Ocean Drilling Program), 351-365, https://doi.org/10.2973/odp.proc.sr.151.124.1996, 1996.

Firth, J. V., Eldrett, J. S., Harding, I. C., Coxall, H. K., and Wade, B. S.: Integrated biomagnetochronology for the Palaeogene of ODP Hole 647A: implications for correlating palaeoceanographic events from high to low latitudes, Geol. Soc. Lond. Spec. Publ., 373, 29-78, https://doi.org/10.1144/SP373.9, 2013.

Friis, H.: Lithostratigraphy and sedimentary petrography of the Oligocene sediments from Harre borehole, Denmark, in: Lithostratigraphy and biostratigraphy of the Tertiary sequence from the Harre borehole, Denmark, edited by: Nielsen, O. B., Vol. 1, 3545, Aarhus Geoscience, Department of Earth Sciences, Aarhus University, 1994.

Gedl, P.: Dinoflagellate cyst record of the Eocene-Oligocene boundary succession in flysch deposits at Leluchów, Carpathian Mountains, Poland, Geol. Soc. Lond. Spec. Publ., 230, 309-324, https://doi.org/10.1144/GSL.SP.2004.230.01.13, 2004.

Haeckel, E.: Systematische Phylogenie. Entwurf eines natürlichen Systems der Organismen auf Grund ihrer Stammegeschichte, I. Systematische Phylogenie der Protisten und Pflanzen, Berlin, Reimer, XV+400 pp., 1894.

Head, M. J.: A palynological investigation of Tertiary strata at Renardodden, W. Spitsbergen, 6th International Palynological Conference, Abstracts Vol., p. 61, Calgary, Canada, 6th International Palynology Conference, 1984.
Head, M. J. and Norris, G.: Palynology and dinocyst stratigraphy of the Eocene and Oligocene in ODP Leg 105, Hole 647A, Labrador Sea, Ocean Drilling Program, Proceedings, Scientific Results, Vol. 105, College Station, TX (Ocean Drilling Program), 515-550, 1989.

Heilmann-Clausen, C. and Van Simaeys, S.: Dinoflagellate cysts from the Middle Eocene to lowermost Oligocene succession in the Kysing research borehole, central Danish basin, Palynology, 29, 143-204, https://doi.org/10.1080/01916122.2005.9989606, 2005.

Iakovleva, A. I.: Palynological reconstruction of the Eocene marine palaeoenvironments in south of Western Siberia, Acta Palaeobotanica, 51, 229-248, 2011.

Ioannides, N. S.: Dinoflagellate cysts from Upper CretaceousLower Tertiary sections, Bylot and Devon Islands, Arctic archipelago, Geological Survey of Canada, Bulletin, 37, 1-99, 1986.

Lentin, J. K. and Williams, G. L.: A monograph of fossil peridinioid dinoflagellate cysts, Bedford Institute of Oceanography, Report Series, no. BI-R-75-16, 237 pp., 1976 (cover date 1975, issue date 1976).

Lindgren, S.: Acid resistant peridinioid dinoflagellates from the Maastrichtian of Trelleborg, southern Sweden, Acta Universitatis Stockholmiensis, Stockholm Contributions in Geology, 39, 145201, 1984.

Manum, S. B.: Some dinoflagellates and hystrichosphaerids from the Lower Tertiary of Spitsbergen, Nytt Magasin for Botanikk, 8, 17-26, 1960.

Manum, S. B.: Dinocysts in Tertiary Norwegian-Greenland Sea sediments (Deep Sea Drilling Project Leg 38) with observations on palynomorphs and palynodebris in relation to environment, in: Initial Reports of the Deep Sea Drilling Project, Volume 38, edited by: Talwani, M., Udintsev, G., et al., Washington (U.S. Govt. Printing Office), 897-919, https://doi.org/10.2973/dsdp.proc.38.129.1976, 1976.

Manum, S. B., Boulter, M. C., Gunnarsdottir, H., Rangnes, K., and Scholze, A.: Eocene to Miocene palynology of the Norwegian Sea (ODP Leg 104), in: Proceedings of the Ocean Drilling Program, Scientific Results, Vol. 104, edited by: Eldholm, O., Thiede, J., and Taylor, E., College Station, TX (Ocean Drilling Program), 611-662, https://doi.org/10.2973/odp.proc.sr.104.176.1989, 1989.

Nøhr-Hansen, H.: Dinoflagellate cyst stratigraphy of the Palaeogene strata from the Hellefisk-1, Ikermiut-1, Kangâmiut-1, Nukik-1, Nukik-2 and Qulleq-1 wells, offshore West Greenland, Mar. Petrol. Geol., 20, 987-1016, https://doi.org/10.1016/S02648172(02)00116-2, 2003.

Norris, R. D., Wilson, P. A., Blum, P., Fehr, A., Agnini, C., Bornemann, A., Boulila, S., Bown, P. R., Cournede, C., Friedrich, O., Ghosh, A. K., Hollis, C. J., Hull, P. M., Jo, K., Junium, C. K., Kaneko, M., Liebrand, D., Lippert, P. C., Liu, Z., Matsui, H., Moriya, K., Nishi, H., Opdyke, B. N., Penman, D., Romans, B., Scher, H. D., Sexton, P., Takagi, H., Turner, S. K., Whiteside, J. H., Yamaguchi, T., and Yamamoto, Y.: Site U1411, Proceedings of the Integrated Ocean Drilling Program, 342, 1-76, https://doi.org/10.2204/iodp.proc.342.112.2014, 2014.

Pascher, A.: Über Flagellaten und Algen, Deutsche Botanische Gesellschaft, Berichte, 32, 136-160, 1914. 
Poulsen, N. E., Manum, S. B., Williams, G. L., and Ellegaard, M.: Tertiary dinoflagellate biostratigraphy of Sites 907, 908, and 909 in the Norwegian-Greenland Sea, Proceedings of the Ocean Drilling Program, Scientific Results, Vol. 151, College Station, TX (Ocean Drilling Program), 255-287, https://doi.org/10.2973/odp.proc.sr.151.1996, 1996.

Pross, J., Houben, A. J. P., van Simaeys, S., Williams, G. L., Kotthoff, U., Coccioni, R., Wilpshaar, M., and Brinkhuis, H.: Umbria-Marche revisited: A refined magnetostratigraphic calibration of dinoflagellate cyst events for the Oligocene of the Western Tethys, Rev. Palaeobot. Palyno., 158, 213-235, https://doi.org/10.1016/j.revpalbo.2009.09.002, 2010.

Schiøler, P.: Dinoflagellate cysts and acritarchs from the OligoceneLower Miocene interval of the Alma-1X well, Danish North Sea, J. Micropalaeontol., 24, 1-37, https://doi.org/10.1144/jm.24.1.1, 2005.

Śliwińska, K. K.: Early Oligocene dinocysts as a tool for palaeoenvironment reconstruction and stratigraphical framework - a case study from a North Sea well, J. Micropalaeontol., 38, 143-176, https://doi.org/10.5194/jm-38-143-2019, 2019.

Śliwińska, K. K. and Heilmann-Clausen, C.: Early Oligocene cooling reflected by the dinoflagellate cyst Svalbardella cooksoniae, Palaeogeogr. Palaeocl., 305, 138-149, https://doi.org/10.1016/j. palaeo.2011.02.027, 2011.

Śliwińska, K. K., Clausen, O. R., and Heilmann-Clausen, C.: A mid-Oligocene cooling (Oi-2b) reflected in the dinoflagellate record and in depositional sequence architecture. An integrated study from the eastern North Sea Basin, Mar. Petrol. Geol., 27, 1424-1430, https://doi.org/10.1016/j.marpetgeo.2010.03.008, 2010.

Śliwińska, K. K., Abrahamsen, N., Beyer, C., Brünings-Hansen, T., Thomsen, E., Ulleberg, K., and Heilmann-Clausen, C.: Bio- and magnetostratigraphy of Rupelian-mid Chattian deposits from the Danish land area, Rev. Palaeobot. Palyno., 172, 48-69, https://doi.org/10.1016/j.revpalbo.2012.01.008, 2012.

Śliwińska, K. K., Heilmann-Clausen, C., and Thomsen, E.: Correlation between the type Chattian in NW Europe and the RupelianChattian candidate GSSP in Italy, in: STRATI 2013, edited by: Rocha, R., Pais, J., Kullberg, J., and Finney, S., 283-286, Springer Geology, Springer, Cham., https://doi.org/10.1007/9783-319-04364-7_57, 2014a.

Śliwińska, K. K., Schouten, S., and Dybkjaer, K.: Lower Eocene to Lower Miocene stratigraphy and palaeoenvironment of ODP Site 643A, Norwegian Sea, in: STRATI 2013, edited by: Rocha, R., Pais, J., Kullberg, J., and Finney, S., 143-147, Springer Geology, Springer, Cham., https://doi.org/10.1007/978-3-319-043647_29, 2014b.

Śliwińska, K. K., Heilmann-Clausen, C., Schouten, S., Thomsen, E., and Van Simaeys, S.: The signature of the Middle Eocene Climatic Optimum (MECO) in a hemipelagic, upper bathyal North Sea Basin sequence (the Kysing-4 borehole, Danmark), in: Conference abstract, 12th International Conference on Paleocenography, p. 1, Utrecht, https://doi.org/10.13140/RG.2.2.27280.25604, 2016.
Strauss, C., Lund, J. J., and Lund-Christensen, J.: Miocene dinoflagellate cyst biostratigraphy of the Nieder Ochtenhausen research borehole (NW Germany), Geologisches Jahrbuch, Reihe A, 152, 395-447, 2001.

Thomsen, E., Abrahamsen, N., Heilmann-Clausen, C., King, C., and Nielsen, O. B.: Middle Eocene to earliest Oligocene development in the eastern North Sea Basin: Biostratigraphy, magnetostratigraphy and palaeoenvironment of the Kysing-4 borehole, Denmark, Palaeogeogr. Palaeocl., 350-352, 212-235, https://doi.org/10.1016/j.palaeo.2012.06.034, 2012.

Ulleberg, K.: Foraminiferal zonation of the Danish Oligocene sediments, B. Geol. Soc. Denmark, 36, 191-202, 1987.

Vandenberghe, N., Hilgen, F. J., Speijer, R. P., Ogg, J. G., Gradstein, F. M., Hammer, O., Hollis, C. J., and Hooker, J. J.: Chapter 28 - The Paleogene Period, in: The Geologic Time Scale, edited by: Gradstein, F. M., Ogg, J. G., Schmitz, M., and Ogg, G. M., 855-921, Elsevier, https://doi.org/10.1016/B978-0-44459425-9.00028-7, 2012.

Van Mourik, C. A. and Brinkhuis, H.: The Massignano EoceneOligocene golden spike section revisited, Stratigraphy, 2, 13-30, 2005.

van Peer, T. E., Liebrand, D., Xuan, C., Lippert, P. C., Agnini, C., Blum, N., Blum, P., Bohaty, S. M., Bown, P. R., Greenop, R., Kordesch, W. E. C., Leonhardt, D., Friedrich, O., and Wilson, P. A.: Data report: revised composite depth scale and splice for IODP Site U1406, in: Proceedings of the Integrated Ocean Drilling Program, 342, edited by: Norris, R. D., Wilson, P. A., Blum, P., and Expedition 342 Scientists, College Station, TX (Integrated Ocean Drilling Program), https://doi.org/10.2204/iodp.proc.342.202.2017, 2017.

Van Simaeys, S., Brinkhuis, H., Pross, J., Williams, G. L., and Zachos, J. C.: Arctic dinoflagellate migrations mark the strongest Oligocene glaciations, Geology, 33, 709-712, https://doi.org/10.1130/G21634.1, 2005.

Williams, G. L. and Manum, S. B.: Oligocene-Early Miocene dinocyst stratigraphy of Hole 985a (Norwegian Sea), in: Proceedings of the Ocean Drilling Program, Scientific Results, Vol. 162, edited by: Raymo, M. E., Jansen, E., Blum, P., and Herbert, T. D., College Station, TX (Ocean Drilling Program), 99 109, https://doi.org/10.2973/odp.proc.sr.162.030.1999, 1999.

Wilson, G. J.: Observations on European Late Cretaceous dinoflagellate cysts, in: Proceedings Second Planktonic Conference Rome, 1970, edited by: Farinacci, A., Edizioni Technoscienza, Rome, Vol. 2, 1259-1275, 1971.

Wilson, G. J.: A new species of Svalbardella Manum (dinophyceae) from the Eocene of New Zealand, New Zeal. J. Geol. Geop., 20, 563-566, https://doi.org/10.1080/00288306.1977.10427601, 1977.

Wrenn, J. H. and Hart, G. F.: Paleogene dinoflagellate cysts biostratigraphy of Seymour Island, Antarctica, Geol. Soc. Am. Mem., 169, 321-448, 1988. 